\title{
Controle postural de escolares com respiração oral em relação ao gênero $* * * * *$
}

\author{
Postural control of mouth breathing school aged children regarding \\ gender
}

\author{
Bruna Roggia* \\ Bruna Correa** \\ Gabriel Ivan Pranke*** \\ Rudi Facco*** \\ Angela Garcia Rossi****
}

*Fonoaudióloga Clínica. Mestre em Distúrbios da Comunicação Humana pela Universidade Federal de Santa Maria (UFSM). Endereço para correspondência: R. Duque de Caxias, 683 - Faxinal do Soturno - RS - CEP 97220-000

(brunaroggia@yahoo.com.br).

**Fonoaudióloga Clínica. Mestre em Distúrbios da Comunicação Humana pela UFSM.

***Educador Físico. Mestre em Distúrbios da Comunicação Humana pela UFSM.

****Fonoaudióloga. Doutora em Distúrbios da Comunicação Humana pela Universidade Federal de São Paulo (UNIFESP). Professora Adjunta do Departamento de Fonoaudiologia da UFSM.

\section{******Trabalho Realizado no Departamento de Fonoaudiologia da UFSM.}

Artigo Original de Pesquisa

Artigo Submetido a Avaliação por Pares

Conflito de Interesse: não

Recebido em 28.04.2010.

Revisado em 16.10.2010; 22.11.2010. Aceito para Publicação em 23.11.2010.

\begin{abstract}
Background: postural control of mouth breathing school aged children. Aim: to compare the posture and body balance of school aged children groups, with and without oral breathing considering the variable gender. Method: the study was developed at a municipal school in the city of Santa Maria (Brazil) and received prior approval of the ethics committee of the University of Santa Maria. The study group (with oral breathing) and the control group (without oral breathing) were selected based on an anamnesis, age (between 8 and 12 years), assessment of the stomatognathic system and auditory evaluation. The final sample was composed by 51 children in the study group (20 female and 31 male) and 58 in the control group (34 female and 24 male). Both groups were submitted to a dynamic posturography (sensory organization test - SOT) and to a postural assessment in right and left lateral view. Results: regarding the female gender, a statistically significant difference was observed for the angle that evaluates head horizontal alignment; for the SOT III value and for all SOT mean values. As for the male gender, a significant numerical difference was observed for the knee angle, for the ankle angle, for the SOT III value, for the SOT IV value and for all SOT mean values. Conclusion: school aged children with oral breathing present postural alterations; females present head positing alterations and males present alterations in the position of the inferior limbs. The body balance of school aged children with oral breathing, of both genders, demonstrated to be altered when compared to children without oral breathing, especially in the presence of sensorial conflict.
\end{abstract}

Key Words: Posture; Postural Balance; Sex; Stomatognathic System; Mouth Breathing.

\section{Resumo}

Tema: controle postural de escolares com respiração oral. Objetivo: comparar postura e equilíbrio corporal entre os grupos de escolares com e sem respiração oral considerando a variável gênero. Método: o estudo foi realizado em uma escola municipal da cidade de Santa Maria; foi aprovado pelo Comitê de Ética da Universidade Federal de Santa Maria. O grupo estudo (com respiração oral) e o grupo controle (sem respiração oral) foram selecionados, baseados na anamnese, na idade (entre 8 a 12 anos), na avaliação do sistema estomatognático e na avaliação auditiva. A amostra final ficou composta por 51 escolares no grupo estudo (20 gênero feminino e 31 gênero masculino) e 58 escolares no grupo controle (34 gênero feminino e 24 gênero masculino). Ambos os grupos foram submetidos à posturografia dinâmica (teste de organização sensorial -TOS - e análise sensorial) e à avaliação postural em vista lateral direita e esquerda. Resultado: no gênero feminino encontrou-se diferença estatisticamente significante nos valores obtidos no ângulo que analisa o alinhamento horizontal da cabeça, nos valores do TOS III e no valor médio de todos os TOS. No gênero masculino verificou-se diferença numericamente significante nos valores obtidos no ângulo do joelho, no ângulo do tornozelo, no TOS III, TOS IV e no valor médio de todos os TOS. Conclusão: escolares com respiração oral apresentam alterações posturais; no gênero feminino no posicionamento cefálico e no masculino em membros inferiores. O equilíbrio corporal dos escolares com respiração oral, em ambos os gêneros, mostrou estar mais prejudicada em relação aos escolares sem respiração oral, principalmente na presença de conflito sensorial.

Palavras-Chave: Postura; Equilíbrio Postural; Sexo; Sistema Estomatognático; Respiração Oral.

Referenciar este material como:

1 Roggia B, Correa B, Pranke GI, Facco R, Rossi AG. Postural control of mouth breathing school aged children regarding gender (original title: Controle postural de $\sum 3$ escolares com respiração oral em relação ao gênero). Pró-Fono Revista de Atualização Científica. 2010 out-dez;22(4):433-8. 


\section{Introduction}

To maintain the bipedal posture is necessary an active postural control system, ie, we need efficient body balance and proper posture1-2.

Body balance is a dynamic moment that can be maintained even in the presence of corporal ocilation3. This phenomenon occurs due to the integration of information systems of visual, somatosensory and vestibular4-6. Since the body posture is a static time period of oscillation very restricted3. Thus, it is characterized by the harmony of the body segments with the segments themselves and with the environment7.

Dysfunction of any origin can affect the postural control system8. Mouth breathing has been studied as a precursor of postural changes in children. This mode causes neuromusculares respiratory adaptations 9-10 that can compromise the body balance.

Regarding gender, it was found that male children have higher rates of postural change1112. Regarding the balance, it was found that female children can make better use of vestibular information, featuring a more effective balanced5, 13. Thus, the objective of this research is to compare body posture and balance between groups of students with and without mouth breathing, considering the variable gender.

\section{Method}

The study is part of a project to evaluate the neurological aspects and auditory processing in school. The project was approved by the ethics committee of Universidade Federal de Santa Maria (UFSM) and is registered under the protocol number 0242.0.243.000-08. The data from this survey were collected in a Municipal School Elementary School in Santa Maria - RS.

To define the control group and study group was considered age (8-12 years), medical history, assessment of the stomatognathic system and audiological evaluation. The case histories were distributed to all parents or guardians, along the border of informed consent (IC). For this research we considered only those questions relating to major clinical signs of mouth breathing (snoring, daytime and nighttime breathing mode, and school difficulties in concentrating, drowsiness, ear infections, allergies or respiratory problems, among others).

With the evaluation of the stomatognathic system, we sought to detect the main clinical features of oral breathing (type straight face, tone of tongue, cheeks and lips reduced, malocclusion, lip posture ajar, dark circles, among others). The breathing mode was investigated by testing water14. Hearing evaluation (otoscopy, audiometry, speech audiometry and tympanometry) was performed in the laboratory of otology at the Hospital Universitário de Santa Maria (HUSM) (audiological diagnostics based on Davis and Silverman15 and Katz16).

They were part of the criteria for inclusion in the study group as three or more symptoms compatible with oral breathing in history and three or more characteristics of oral breathing in the evaluation of the stomatognathic system. Were defined as exclusion criteria for both groups: lack of signed Informed Consent; hearing loss, mobility limitations, neurological signs, visual impairment, use of antivertigo drugs; orthodontic treatment, physiotherapy or speech and language in less than six months. For the control group it was felt, too, frequent respiratory complaints.

The study group was composed of 51 students, 31 were males (mean age 9.12) and 20 females (mean age 9.25) and a control group of 58 students, including 24 males (mean age 9, 54) and 34 females (mean age 9.26).

Postural findings were obtained through the Positional Analysis Software - SAPO ® 17. Two photographic images were taken: right and left lateral view. We opted for a sagittal view because they see more clearly the postural oral disorders9 on respirators. We used a digital camera (Sony, resolution of 4.1 megapixels, 3.0x zoom). The marking of bony prominences was performed with polystyrene spheres $(5 \mathrm{~mm})$ at the points stipulated by the protocol SAPO ® . The preparation of the environment and evaluated for the photos also occurred as SAPO ${ }^{\circledR}$ protocol.

Among the various angles measured by SAPO ${ }^{\circledR}$, only five were selected. All were measured in degrees $\left(^{\circ}\right)$.

1. Horizontal alignment of the head: angle between the tragus, C7 spinous process and the horizontal. The smaller the angle, the greater the forward head posture.

2. Vertical alignment of the body: the angle between acrônio, vertical and lateral malleolus. Positive angular measure: body leaning forward, as negative, backward.

3. Horizontal alignment of the pelvis: the angle between the anterior superior iliac spine, posteriorsuperior and horizontal. Negative angular measurement: concavity; close to zero: rectification, the less negative, closer to normal.

4. Knee angle: angle between the greater trochanter, the knee joint line and lateral malleolus 
(posterior angle). Angular measure positive: flexion, negative measure: hyperextension.

5. Ankle angle: angle between the knee joint line, lateral malleolus and horizontal. Measure angle $>90$ : tibia tilted back, as $<90$ : tibial bending forward.

Postural assessment and data interpretation were conducted by a team of physical educators and physiotherapists UFSM.

The school underwent dynamic posturography, an instrument developed by Castagno18 to assess the body balance. In this examination, the individual is exposed to six different conditions known as Sensory Organization Test (SOT).

1. SOT I - open eyes, with no pillow and fixed cab. To evaluate the three systems in the absence of sensory conflicts.

2. SOT II - closed eyes, no pillow and fixed cab. Investigates the somatosensory system and vestibular system.

3. SOT III-open eyes, no pillow and swinging cabin. Evaluates the three systems above the visual.

4. SOT IV -open eyes, with pad and fixed cab. It is investigated, especially the somatosensory system. 5. SOT V - closed eyes, with pad and fixed cab. Evaluates somatosensory and visual system in overload conditions.

6. SOT VI - open eyes, with pad and oscillating cabin. To evaluate the three systems in a condition of sensory conflict.

Each test lasts for twenty seconds and in that time, there is the anterior-posterior maximum obtained. The final values of each SOT are incorporated into formulas for calculating the oscillation.

The formula gives the value of each SOT and the value of each system:
$\mathrm{I}$;

. somatosensory system: SOT II divided by SOT

. visual system: SOT IV TOS divided by SOT I; . vestibular system: SOT V divided by SOT I.

Statistical analysis was first performed to compare the angles between the right and left side view by means of the Wilcoxon test with a significance level of $5 \%(p<0.05)$. This comparison was performed to determine whether there is influence of different views in the adjustment of posture. In cases where there were no statistically significant differences, the right and left lateral view were combined to make larger sample size. To compare values obtained in the assessment of posture and body balance between groups with respect to gender, was used to test Krukal-Wallis test with a significance level of $5 \%(\mathrm{p}<0.05)$.

\section{Results}

There was no statistical difference when comparing the results obtained in right and left lateral view in both genders in the control group and also in females in the study group. However, in male study group was found statistically significant differences in knee angle (Table 1).

The remaining variables of postural assessment has joined the right and left lateral view. Thus, the sample consisted of 68 profiles in females and 48 males in the profiles within the control group. Already, the group studied, the overall profile was evaluated in 62 males and 40 for females (Table 2).

T ABLE 1. Comparison of mean values obtained in the postural side view of right and left school boys in the study group.

\begin{tabular}{|c|c|c|c|}
\hline & \multicolumn{2}{|c|}{ Gender Male Stu dy Group } & \multirow[b]{2}{*}{$\mathrm{p}$} \\
\hline & $\begin{array}{l}\text { Right Side View } \\
\text { Mean } \pm \text { SD }\end{array}$ & $\begin{array}{l}\text { Left Side View } \\
\text { Mean } \pm \text { SD } \\
\end{array}$ & \\
\hline head & $49.31 \pm 5.63$ & $49.09 \pm 8.04$ & 0.6947 \\
\hline $\log$ & $3.56 \pm 1.59$ & $2.96 \pm 1.51$ & 0.0583 \\
\hline pelvis & $-17.83 \pm 5.65$ & $-18.04 \pm 5.11$ & 0.4841 \\
\hline knee & $3.70 \pm 6.28$ & $-0.41 \pm 6.03$ & $0.0143^{*}$ \\
\hline ankle & $84.21 \pm 3.25$ & $85.28 \pm 2.95$ & 0.1814 \\
\hline
\end{tabular}


TABLE 2. Comparison of mean values obtained in the assessment of po stural control and study group in a side view of the variable gender.

\begin{tabular}{|c|c|c|c|c|c|c|}
\hline \multicolumn{3}{|c|}{ Female Gender } & & \multicolumn{2}{|c|}{ Gênero masculino } & \multirow[b]{2}{*}{$\mathrm{p}$} \\
\hline & $\begin{array}{c}\text { Control Group } \\
\text { Mean } \pm \text { SD }\end{array}$ & $\begin{array}{l}\text { Study Group } \\
\text { Mean } \pm \text { SD }\end{array}$ & & $\begin{array}{c}\text { Control Group } \\
\text { Mean } \pm \text { SD }\end{array}$ & $\begin{array}{l}\text { Study Group } \\
\text { Mean } \pm \text { SD }\end{array}$ & \\
\hline head & $49.49 \pm 6.01$ & $46.95 \pm 5.65$ & $0,0486 *$ & $50.05 \pm 5.77$ & $49.20 \pm 6.89$ & 0,2860 \\
\hline $\log$ & $2.69 \pm 1.40$ & $2.94 \pm 1.22$ & 0,5754 & $3.63 \pm 1.16$ & $3.26 \pm 1.57$ & 0,1897 \\
\hline pelvis & $-12.87 \pm 6.17$ & $-11.65 \pm 5.11$ & 0,1291 & $-15.56 \pm 5.27$ & $-17.94 \pm 5.34$ & 0,0584 \\
\hline ankle & $84.19 \pm 3.46$ & $84.49 \pm 2,96$ & 0,8238 & $83.10 \pm 2.74$ & $84.74 \pm 3.12$ & $0,0034^{*}$ \\
\hline
\end{tabular}

Legend: SD: standard deviation * statistically significant diff erence.

TABLE 3. Comparison of mean values obtained in the evaluation of body balance students' study and control groups considering the gender variable.

\begin{tabular}{|c|c|c|c|c|c|c|}
\hline & \multicolumn{2}{|l|}{ Female Gender } & \multicolumn{4}{|c|}{ Gênero masculino } \\
\hline & Control Group & Study Group & & Control Group & Study Group & \\
\hline & Mean \pm SD & Mean \pm SD & & Mean \pm SD & Mean \pm SD & $\mathrm{p}$ \\
\hline SOT I & $74.82 \pm 8.46$ & $65.33 \pm 18.09$ & 0,0618 & $70.99 \pm 10.20$ & $59.70 \pm 21.25$ & 0.0819 \\
\hline SOT II & $68.30 \pm 10.39$ & $59.15 \pm 18.18$ & 0,0509 & $63.73 \pm 18.72$ & $57.50 \pm 20.24$ & 0.2282 \\
\hline SOT III & $60.93 \pm 17.72$ & $44.04 \pm 19.85$ & $0,0006^{*}$ & $58.90 \pm 20.49$ & $46.91 \pm 20.63$ & $0.0145^{*}$ \\
\hline SOT IV & $70.84 \pm 12.91$ & $60.98 \pm 20.36$ & 0,0564 & $65.98 \pm 13.79$ & $56.05 \pm 16.46$ & $0.0325 *$ \\
\hline SOT V & $58.05 \pm 12.92$ & $50.94 \pm 18.10$ & 0,1468 & $52.34 \pm 20.31$ & $43.40 \pm 19.66$ & 0.0897 \\
\hline SOT VI & $45.19 \pm 19.34$ & $35.29 \pm 23.27$ & 0,1443 & $40.11 \pm 21.19$ & $32.45 \pm 20.08$ & 0.1204 \\
\hline Average & $63.02 \pm 10.07$ & $52.59 \pm 15.35$ & $0,0052 *$ & $58.68 \pm 14.22$ & $49.35 \pm 15.10$ & $0.0183^{*}$ \\
\hline SOM & $91.97 \pm 15.08$ & $90.68 \pm 17.12$ & 0,8157 & $89.07 \pm 24.99$ & $107.61 \pm 62.43$ & 0.5286 \\
\hline VIS & $94.95 \pm 15.57$ & $95.39 \pm 33.13$ & 0,3836 & $92.78 \pm 13.62$ & $112.39 \pm 96.97$ & 0.7469 \\
\hline VEST & $77.99 \pm 17.26$ & $79.26 \pm 32.64$ & 0,8719 & $72.62 \pm 26.50$ & $81.80 \pm 60.61$ & 0.6103 \\
\hline
\end{tabular}

L egend: SOT: sensory organization tests; sound: somatosensory; vest: vestibu lar; vis: visual, SD = standard deviation * statistically sign ificant difference.

\section{Discussão}

In Table 1 there was only statistically significant difference in knee angle $(\mathrm{p}=0.0178)$. According to the mean value found in the mouth breathers males have hyperextended knee.

The finding may be related to orthostatic posture adopted (most support in either lower limb) or with postural changes caused by mouth breathing and influenced by the pattern of dominance body. Described in the literature is that the pattern of dominance and plays an active role at an early age on the adjustment of the corporal segments19. In a survey conducted to verify the dominance side of schoolchildren, aged 7 to 10 years in various genres, was found handedness, foot and right eye20.

In this study, possibly, the hyperextension is related to mouth breathing, since the change was found in the left lateral side on the body used less and less likelihood of interference by use.

In Table 2, when considering the side view (regardless of side), there was a statistically significant difference in the positioning head, just in school females $(p=0.0486)$. Thus, it appears that girls with mouth breathing have more anterior head (46.95) compared to girls without mouth breathing (49.49).

Anterior head of female children was found in a study assessing the body posture in girls 70 to 10 years21. Other researchers found that female children have head more anterior when compared to children's male gender 12 .

The literature indicates that the forward positioning of the head is one of the major changes found in respirators orais22-24. The forward head is to increase the glottis and facilitate the flow passage aéreo9-10. The results of this study agrees with the studies and adds that such compensation occurs mainly in children with mouth breathing female.

The statistically significant difference in values found in the ankle angle ( $\mathrm{p}=0.0034)$, were visualized only in school boys (Table 2). This could be associated with one of the compensatory 
strategies used to, coupled with hyperextension of the knee allows the maintenance of posture and body balance.

It was observed that male students had higher number of posture changes when compared to female students. This result does not agree with the findings of some researchers25. However, it encounters recent findings 11-12. Regarding gender, we found only one study of nasal and oral breathing. In this study no differences were seen between genres9.

Possibly, the students were female with mouth breathing, the forward head is the only abnormality found, since the other structures are undergoing changes of its own female (increased size of the hips and torso). For males, the changes occurring in the lower limbs, probably due to the weakness of the muscles, especially abdominal 26-27. A recent study found that the distance toured the diaphragm muscle is lower in mouth breathing, which also demonstrates that greater muscle weakness group24.

Table 3 shows that low scores on the SOT III of the study group to evaluate both the female $(\mathrm{p}=$ 0.0006), as the male ( $p=0.0145)$. The literature indicates that children are dependent on vision for balance and corporal28-29, which could be observed, given the values obtained in SOT III in both sexes, is that children with mouth breathing are even more dependent on the visual system to maintain body balance. This inference can be accomplished by noting that in SOT III, no modification of somatosensory and vestibular system and visual system the only modified.

Researchers believe that children typically have difficulties in sensory conflict 30 . In one study it was found that these difficulties do not occur due to maturation of systems5.

\section{References}

1. Prado JM, Stoffregen TA, Duarte M. Postural sway during dual tasks in young and elderly adults. Gerontology. 2007;53:274-81.

2. Souza GS, Gonçalves DF, Pastre CM. Propriocepção cervical e equilíbrio: uma revisão. Fisioterapia em movimento. 2006;19(4):33-40.

3. Guidetti G. Diagnosi e terapi del disturbi dell'equilibrio. 2. ed. Roma: Marropense; 1997.

4. Lourenço EA, Lopes KC, Pontes AJ, Oliveira MH, Umemura AE, Vargas AL. Distribuição dos achados otoneurológicos em pacientes com disfunção vestíbulococlear. Rev Bras Otorrinolaringol. 2005;71(3):288-96.
Possibly, this difference was only found in the values obtained in the TOS IV ( $\mathrm{p}=0.0325)$ in male schoolchildren (Table 3), due to the structures of the somatosensory system, altered as a result of postural adjustments in the lower limbs added to the somatosensory modification created by the test itself.

From these results, it was observed that there is a greater number of tests of balance altered in male schoolchildren when compared to female students. Probably the body balance is worse in males compared to females.

In the literature we found that female children have a better body balance, especially with regard to the vestibular system. The authors attribute this finding to the different experiences and activities that boys and girls play13.

Considering the average of the SOT, we found that in both genders, body balance school with mouth breathing is worse when compared to students without mouth breathing. From these averages, it appears that the diagnosis of oral breathing, speech therapy affects body balance.

\section{Conclusion}

School with mouth breathing, both male and female, have postural changes. For females the change is the placement head, more anterior in mouth breathers. For males the changes are at the level of the lower limbs (knee and ankle).

Body balance of children with mouth breathing, in both genders, is more impaired than schoolchildren without mouth breathing, especially in the presence of sensory conflict.
5. Peterson ML, Christou E, Rosengren KS. Children achieve adult-like sensory integration during stance at 12-yearsold. Gait Posture. 2006;23:455-63.

6. Stack B, Sims A. The relationship between posture and equilibrium and the auriculotemporal nerve in patients with disturbed gait and balance.Cranio. 2009;27(4):248-60.

7. Horak FB, Macpherson JM. Postural orientation and equilibrium. In: Rowell, Horak FB, Shepard JT. Handbook of phisiology. New York: Oxford university Press; 1996.

8. Latash ML, Krishnamoorthy V, Scholz JP, Zatsiorsky VM. Postural synergies and their development. Neural Plast. 2005;12 (2-3):119-30. 
9. Krakauer LH, Guilherme A. Relação entre respiração bucal e alterações posturais em crianças: uma análise descritiva. R Dental Press Ortodon Ortop Facial. 2000;5(5):85-92.

10. Muto T, Yamazaki A, Takeda S, Kawakami J, Tsuji Y, Shibata $\mathrm{T}$ et al. Relationship between the pharyngeal airway space and craniofacial morphology, taking into account head posture. Int J Oral Maxillofac Surg. 2006;35:132-36.

9. Kratenová J, Zejglicová K, Malý M, Filipová V. Prevalence and risk factors of poor posture in school children in the Czech Republic. J Sch Health. 2007 Mar 77(3):131-37.

10. Penha PJ, Baldini M, João SM. A. Spinal postural alignment variance according to Sex and age in 7- and 8year-old children. J Manipulative Physiol Ther. 2008;32(2):154-9.

11. Hirabayashi S, Iwasaki Y. Developmental perspective of sensory organization on postural control. Brain Dev. 1995; 17:111-3.

12. Ferreira LP. Respiração: tipo, capacidade e coordenação pneumofonoarticulatória. In: Ferreira et al. Temas de fonoaudiologia. São Paulo: Loyola; 1984 Cap. 1, 9-39.

13. Davis H, Silverman RS. Hearing and deafness. 3a ed. New York: Holt, Rinehart \& Wilson; 1970.

14. Katz, Jack. Tratado de audiologia clínica. 4a ed. São Paulo: Manole; 1999.

15. Portal do projeto software para avaliação postural [homepage na Internet]. São Paulo: Incubadora Virtual Fapesp; 2004 [atualizada em 06 Jan 2007; acesso em 05 março 2008]. Disponível em: http:// sapo.incubadora.fapesp.br/portal

16. Castagno LA. Distúrbio do equilíbrio: um protocolo de investigação racional. Rev. Brás. Otorinolaringol. 1994;60(2):124-41.

17. Kendall FP, Mccreary BA, Provance, PG. Músculos, provas e funções. 4a ed. São Paulo: Manole; 1995 Cap. 4, 70-117.

18. Serafin G. Perez l. Corseuil HX. Lateralidade: conhecimentos básicos e fatores de dominância em escolares de 7 a 10 anos. Caderno de Ed. Física. 2000;2(1):11-30.
19. Penha PJ, João SMA, Casarotto RA, Amino CJ, Penteado DC. Postural assessment of girls between 7 and 10 years of age. Clinics. 2005;60(1):9-16.

20. Cuccia AM, Lotti M, Caradonna D. Oral Breathing and Head Posture. Angle Orthod. 2008;78(1):77-82.

21. Neiva PD, Kirkwood RN, Godinho, R. Orientation and position of head posture, scapula and thoracic spine in mouth-breathing children. Int J Pediatr Otorhinolaryngol. 2009;73:227-36.

22. Yi LC, Jardim JR, Inoue DP, Pignatari SSN. The relationship between the excursion of diaphragm and curvature of spinal column of mouth breathing children. J Pediatr (Rio J). 2008;88(2):171-7.

23. Correa AL, Pereira JS, Silva MAG. Avaliação dos desvios posturais em escolares: estudo preliminar. Fisioterapia Brasil. 2005;6(3):175-8.

24. Weckx LLM, Weckx LY. Respirador bucal: causas e conseqüências. RBM. 1995;52(8):863-74.

25. Aragão W. Respirador bucal. J Pediatr (Rio J). 1988;64(8):349-52.

26. Ionescu EA, Morlet BT, Froehlich PC, Ferber-Viart $\mathrm{CD}$. Vestibular assessment with balance quest normative data for children and young adults. Int $\mathrm{J}$ Pediatr Otorhinolaryngol. 2006;70:1457-65.

27. Ferber-Viart C, Ionescu I, Morlet T, Froehlich P, Dubreuil C. Balance in healthy individuals assessed with Equitest: Maturation and normative data for children and young adults. Int J Pediatr Otorhinolaryngol. 2007;71:1041-6.

28. Cherng RJ, Chen JJ. Vestibular system in performance of standing balance of children and young adults under altered sensory condition. Percept Mot Skills . 2001;92:1167-79

29. Ferber-Viart C, Ionescu I, Morlet T, Froehlich P, Dubreuil C. Balance in healthy individuals assessed with Equitest: Maturation and normative data for children and young adults. Int J Pediatr Otorhinolaryngol. 2007;71:1041-6.

30. Cherng RJ, Chen JJ. Vestibular system in performance of standing balance of children and young adults under altered sensory condition. Percept Mot Skills . 2001;92:1167-79. 